J. MAJ' ${ }^{1}$, A. RYDLEWSKA ${ }^{1,2}$, B. PONIKOWSKA ${ }^{3}$, W. BANASIAK ${ }^{1}$,

P. PONIKOWSKI ${ }^{1,2}$, and E. A. JANKOWSKA ${ }^{1,2}$

\title{
HYPERCAPNIC CHEMOSENSITIVITY IN PATIENTS WITH HEART FAILURE: RELATION TO SHIFTS IN TYPE-1 INSULIN-LIKE GROWTH FACTOR AND SEX HORMONE-BINDING GLOBULIN LEVELS
}

Received October 15, 2012.

\begin{abstract}
In patients suffering from heart failure (HF), autonomic imbalance develops even at early stages along with derangements of cardiopulmonary reflex control and abnormalities in metabolism of several hormones. In 34 men with stable systolic HF, we investigated hypercapnic chemosensitivity (HCS, liter $/ \mathrm{min} \cdot \mathrm{mm} \mathrm{Hg}$ ) measured using the rebreathing method and defined as the slope of the regression line relating minute ventilation (VE, liter/min) to end-tidal carbon dioxide concentration $\left(\mathrm{PETCO}_{2}, \mathrm{~mm} \mathrm{Hg}\right)$. Serum levels of testosterone, dehydroepiandrosterone sulfate, type-1 insulin-like growth factor (IGF-1), sex hormonebinding globulin (SHBG), estradiol, and cortisol were measured using immunoassays. We found that there were no associations between HCS and clinical variables, applied therapy, and co-morbidities (all $P>0.2$ ). Augmented HCS was accompanied by increased serum SHBG (when expressed in $\mathrm{nM}, \mathrm{r}=0.43, P<0.05$; when expressed as percentage of the agematched reference values, $\mathrm{r}=0.62, P<0.001$ ) and the reduced serum IGF-1 (when expressed in $\mathrm{ng} / \mathrm{ml}$ and as percentage of the above-mentioned values, $\mathrm{r}=-0.49, P<0.05$, and $\mathrm{r}=$ $=-0.47, P=0.007$, respectively). The HCS was not related to serum levels of all the remaining analyzed hormones (all $P>0.2$ ). Thus, it may be suggested that the hormone stimuli can noticeably modify the reflex mechanisms in cardiorespiratory control in the clinical setting of cardiovascular pathology.
\end{abstract}

\section{Keywords: hypercapnic chemosensitivity, IGF-1, SHBG, heart failure.}

\section{INTRODUCTION}

The complex pathophysiology of systolic heart failure (HF) involves, in addition to hemodynamic abnormalities, the dysfunction of most body organs, including the autonomic nervous and endocrine systems $[1,2]$. Augmented hypercapnic chemosensitivity (HCS) reflects considerably deranged cardiopulmonary reflex control $[3,4]$ manifested, in particular, in patients with HF $[2,5,6]$. This phenomenon is linked to exercise intolerance and poor outcome and mostly occurs at early stages of HF $[2,5,7]$.

Men with systolic HF are characterized by derangements within the functioning of several

\footnotetext{
${ }^{1}$ Center for Heart Diseases, Military Hospital, Wroclaw, Poland.

${ }^{2}$ Laboratory for Applied Research on Cardiovascular System, Faculty of Health Sciences, Wroclaw Medical University, Wroclaw, Poland.

${ }^{3}$ Department of Physiology, Faculty of Health Sciences, Wroclaw Medical University, Wroclaw, Poland.

Correspondence should be addressed to E. A. Jankowska

(e-mail: ewa.jankowska@am.wroc.pl).
}

endocrine glands [8] and demonstrate deficiencies in, e.g., circulating testosterone, dehydroepiandrosterone sulfate (DHEAS), and insulin-like growth factor type 1 (IGF-1), which, independently of each other and of other clinical prognosticators, unfavorably affect the long-term prognosis [9]. A reduced level of serum testosterone is related to a diminished lean tissue mass [10], severe depressive symptoms [11], exercise intolerance [12, 13], and anemia [14]. Moreover, IGF-1 deficiency in this group of patients is associated with further reduction in both exercise capacity [12] and hemoglobin level [14], whereas DHEAS deficiency is linked with augmented depressive symptoms [15]. We have also demonstrated that both low and high circulating estradiol $\left(\mathrm{E}_{2}\right)$ levels are related to increased mortality in men with systolic HF, which may suggest that some optimum $\mathrm{E}_{2}$ levels are advantageous for these patients [16].

The autonomic nervous and endocrine systems are tightly linked to each other due to the anatomical contiguity of the hypothalamic-hypophyseal- 
endocrine gland axis and CNS structures [17]. Sympathetic and parasympathetic neurons within both central and peripheral nervous systems are characterized by the presence of receptors specific for androgens, estrogens, mineralocorticoids, and glucocorticoids $[17,18]$. On the other hand, both gonads and adrenal glands are innervated by autonomic nerve fibers [19].

Hence, taking into consideration these close interplays between the hormonal and autonomic nervous mechanisms $[17,20]$ and experimental evidence that, e.g., estrogens modulate the central autonomic balance [21], we hypothesized that there would be associations between the hormone status (assessed based on circulating levels of certain hormones) and central HCS (reflecting the efficiency of reflex control of respiration). This hypothesis was tested on the patients with systolic HF at the early stage of heart disease.

\section{METHODS}

Examined Group. The recruitment phase of the study was conducted in the Center for Heart Diseases, Military Hospital (Wroclaw, Poland) among patients with systolic HF attending the outpatient HF clinic.

The criteria for study inclusion were: (i) age between 18 and 75 years, (ii) male gender, (iii) a documented history of HF for more than 6 months preceding the study, (iv) HF symptoms corresponding to the functional class (New York Heart Association, NYHA) I-II, (v) clinical stability (i.e., unchanged severity of the signs and symptoms of HF along with unchanged medications) for minimum 3 months preceding the study, and (vi) left ventricular ejection fraction (LVEF) $\leq 45 \%$.

The exclusion criteria were as follows: (i) acute coronary syndrome and/or coronary revascularization within 3 months preceding the study, (ii) unplanned hospitalization due to HF deterioration or any other cardiovascular reason within 3 months preceding the study, (iii) atrial fibrillation, a pacemaker rhythm, and/or frequent ectopics, and (iv) any hormonal dysfunction and/or hormonal therapy (either in the time of the study or in the past).

The study protocol was approved by the local Ethics Committees, and all subjects gave written informed consent. The study was conducted in accordance with the Helsinki Declaration.

Study Protocol. In all patients, venous blood samples were taken in the morning after a supine rest of at least $15 \mathrm{~min}$. After centrifugation, the serum was collected and frozen at $-70^{\circ} \mathrm{C}$ until further analyzed.

The serum levels of total testosterone (TT, ng/ml), DHEAS (ng/ml), $E_{2}(\mathrm{pg} / \mathrm{ml})$, sex hormone-binding globulin (SHBG, nM), and cortisol (nM) were assessed using electrochemiluminescence techniques (Elecsys 2010, Roche Diagnostics, Germany). The serum IGF-1 level (ng/ml) was assessed using an immunochemiluminescence technique (Immulite 2000/2500, Diagnostic Products, USA).

The inter- and intraassay variability coefficients for TT, DHEAS, $E_{2}$, SHBG, cortisol, and IGF-1 were taken as 3 and $4 \%, 2$ and $4 \%, 5$ and $4 \%, 2$ and $4 \%, 1$ and $2 \%$, and 3 and $6 \%$, respectively.

The deficiencies of TT, DHEAS, and IGF-1 were defined prospectively as a serum hormone level less than or equal to the 10 th percentile calculated for the equivalent age categories in the cohort of healthy men, as previously described [9]. Serum TT, DHEAS, and IGF-1 were referred to values assessed among the population of healthy men living in Wroclaw, Poland [9]. Medians of the analyzed serum hormone levels in the age groups 51 to 60,61 to 70 , and older than 71 years were as follows: TT, 4.20, 3.90, and $4.40 \mathrm{ng} / \mathrm{ml}$, DHEAS, 1648, 989, and $936 \mathrm{ng} / \mathrm{ml}$, and IGF-1, 290.1, 268.5, and $229.0 \mathrm{ng} / \mathrm{ml}$ [9].

According to DeGroot and Jameson [22], the $\mathrm{E}_{2}$ excess in men with systolic HF was defined as serum $\mathrm{E}_{2} \geq 50 \mathrm{pg} / \mathrm{ml}$, and the $\mathrm{E}_{2}$ deficiency as serum $\mathrm{E}_{2} \leq$ $\leq 10 \mathrm{pg} / \mathrm{ml}$. The following cut-off values of serum SHBG and cortisol were considered as excess of these hormones: $\geq 50$ and $\geq 700 \mathrm{nM}$, respectively [22].

The level of plasma N-terminal pro-B-type natriuretic peptide (NT-proBNP, pg/ml) was measured using an electrochemiluminescence technique (Elecsys 1010/2010, Roche Diagnostics, Germany). The renal function was assessed based on the estimated glomerular filtration rate (GFR; $\mathrm{ml} / \mathrm{min} \times 1.73 \mathrm{~m}^{2}$ ) [22]. Serum high-sensitive C-reactive protein (hsCRP, $\mathrm{mg} /$ liter) was assessed using immunonephelometry (Dade Behring, Marburg, Germany) [22].

HCS Assessment. The HCS assessments (allowing us to estimate the peculiarities of respiration control) were carried out between 9 and 12 a.m. in an airconditioned room. All subjects were asked to avoid strenuous physical activity for $24 \mathrm{~h}$ before each test and to avoid smoking, eating, or consuming caffeine for $3 \mathrm{~h}$ prior to the study. The tests were preceded by $30 \mathrm{~min}$ of resting in a quiet environment.

The HCS was assessed with a re-breathing method 
$[23,24]$ using a 5-liter bag containing almost $100 \%$ oxygen initially and room air in the remaining volume. During the entire test, minute ventilation (VE; liter/min) and end-tidal carbon dioxide concentration $\left(\mathrm{PETCO}_{2}\right.$, $\mathrm{mm} \mathrm{Hg}$ ) were measured breath by breath using the gas exchange system (BREEZE EX, Cardiorespiratory Diagnostic Software 1991-1996, Medical Graphics, USA). Subjects were wearing a nose clip. The test was divided into three parts: (i) resting recording ( $3 \mathrm{~min}$ ), (ii) re-breathing within a closed circuit (using a 5-liter bag), and (iii) recovery ( $3 \mathrm{~min}$ ). During both resting and recovery stages, subjects were breathing with room air. At the beginning of the second stage, subjects were switched unnoticeably to breathing within a closed circuit. During the re-breathing stage, subjects were exhaling $\mathrm{CO}_{2}$ to a 5-liter bag, which resulted in a steady increase in the $\mathrm{CO}_{2}$ concentration within this bag, and, subsequently, in inhaling a gas mixture with a continuously increasing $\mathrm{CO}_{2}$ concentration in peripheral blood. As a consequence, hypercapnia developed in the subjects, which in turn induced hyperventilation in a reflex manner. This stage was stopped when a subject became either breathless (and informed the staff by tagging at a table), or $\mathrm{PETCO}_{2}$ exceeded $70 \mathrm{~mm} \mathrm{Hg}$. The HCS was defined as the slope of the regression graph relating VE to $\mathrm{PETCO}_{2}$ concentration measured during the re-breathing stage of the test (expressed in liter/min $\cdot \mathrm{mm} \mathrm{Hg}$ ) [23, 24].

Statistical Analyses. Normally distributed continuous variables were presented as means \pm s.d. The intergroup differences were tested using the Student's $t$-test. Variables with a skewed distribution were expressed as medians with lower and upper quartiles and were log-transformed, which enabled normalization of these distributions. Categorical variables were expressed as numbers with percentages. Intergroup differences were tested using the $\chi^{2}$ test. Relationships between continuous variables were calculated using the Pearson's correlation coefficient for variables with a normal distribution or the Spearman's rank correlation coefficient for variables with a skewed distribution.

In intergroup comparisons, values of $P<0.05$ were considered significant.

\section{RESULTS}

Baseline clinical and laboratory parameters are shown in Table 1. Mean values of the serum levels of analyzed hormones along with the prevalence of
Table 1. Baseline Clinical and Laboratory Characteristics of Examined Patients with Mild Systolic Heart Failure (HF)

Т а б л и ц я 1. Вихідні клінічні та лабораторні характеристики досліджених паціснтів 3 помірною систолічною серцевою недостатністю

\begin{tabular}{lc}
\hline $\begin{array}{l}\text { Conditions for examination of } \\
\text { patients with mild systolic HF }\end{array}$ & Variables \\
\hline \multicolumn{2}{c}{ Inclusion criteria } \\
Age & $61 \pm 10$ years \\
BMI & $28.6 \pm 4.0 \mathrm{~kg} / \mathrm{m}^{2}$ \\
NYHA class I/II & $21 / 79 \%$ \\
Etiology (CAD) & $65 \%$ \\
Hypertension (yes) & $62 \%$ \\
DM (yes) & $24 \%$ \\
LVEF & $31 \pm 7 \%$ \\
LVEDD & $66 \pm 8 \mathrm{~mm}$ \\
Hemoglobin & $14.4 \pm 0.9 \mathrm{~g} / \mathrm{dl}$ \\
hsCRP & $1.23(0.98-2.27) \mathrm{mg} / \mathrm{liter}$ \\
GFR & $82.0 \pm 13.6 \mathrm{ml} / \mathrm{min} \cdot 1.73 \mathrm{~m}{ }^{2}$ \\
Na & $141 \pm 3 \mathrm{mEq} / \mathrm{liter}$ \\
NT-proBNP & $655(263-942) \mathrm{pg} / \mathrm{ml}$ \\
& \\
ACE inhibitor and/or ARB & Treatment \\
$\beta$-Blocker & $89 \%$ \\
Aldosterone antagonist & $100 \%$ \\
Loop diuretic & $12 \%$ \\
Thiazide diuretic & $47 \%$ \\
Digoxin & $35 \%$ \\
Statin & $24 \%$ \\
Acetylsalicylic acid & $88 \%$ \\
\hline &
\end{tabular}

Footnotes. Data are presented as means \pm s.d., medians with lower and upper quartiles, or percentage where appropriate. BMI, body mass index; NYHA, New York Heart Association; CAD, coronary artery disease; DM, diabetes mellitus; LVEF, left ventricular ejection fraction; LVEDD, left ventricular end-diastolic diameter; hsCRP, high-sensitivity C-reactive protein; GFR, glomerular filtration rate; NT-proBNP, plasma N-terminal pro-B-type natriuretic peptide; $\mathrm{ACE}$, angiotensin converting enzyme; and ARB, angiotensin receptor blocker.

hormonal abnormalities in men with mild systolic HF are shown in Table 2.

The mean value of HCS in examined men with mild systolic HF was $0.68(0.43-0.95) \mathrm{liter} / \mathrm{min} \cdot \mathrm{mm} \mathrm{Hg}$, and was higher than the reference values assessed in our laboratory $(P<0.01)$.

There were no associations between HCS and clinical variables (including the plasma NT-proBNP level), applied therapy, and co-morbidities (in all cases, $P>0.2)$.

The augmented HCS was accompanied by an increased serum SHBG level, when expressed both in $\mathrm{nM}(\mathrm{r}=0.43, P<0.05$, Fig. 2$)$ and when normalized 
Table 2. Serum Hormone Levels and Frequency of Cases of Hormone Deficiency or Excess in Examined Patients with Mild Systolic Heart Failure (HF)

Т а б л и ц я 2. Рівні гормонів у сироватці крові та частота випадків дефіциту або надлишку гормонів у досліджених пацієнтів 3 помірною систолічною серцевою недостатністю

\begin{tabular}{l|l|c|c}
\hline \multirow{2}{*}{\multicolumn{1}{c}{ Analyzed hormones }} & \multicolumn{2}{c}{ Patients with mild systolic $\operatorname{HP}(n=34)$} \\
\cline { 2 - 4 } & \multicolumn{1}{c}{$\begin{array}{c}\text { mean values of the serum } \\
\text { hormone levels }\end{array}$} & hormone deficiency (\%) & hormone excess $(\%)$ \\
\hline TT & $5.00(4.30-5.80) \mathrm{ng} / \mathrm{ml}$ & 9 & - \\
DHEAS & $558(96-1214) \mathrm{pg} / \mathrm{ml}$ & 47 & - \\
IGF-1 & $114.5(103.0-141.0) \mathrm{ng} / \mathrm{ml}$ & 91 & - \\
SHBG & $46.3(38.5-57.3) \mathrm{nM}$ & 0 & 38 \\
E & $29.4(25.1-31.8) \mathrm{pg} / \mathrm{ml}$ & - & 30 \\
Cortisol & $613(517-718) \mathrm{nM}$ & 0 \\
\hline
\end{tabular}

Footnotes. Data are presented as medians with lower and upper quartiles or percentages where appropriate. TT, total testosterone; DHEAS, dehydroepiandrosterone sulfate; IGF-1, type-1 insulin-like growth factor; SHBG, sex hormone binding globulin, and $\mathrm{E}_{2}$, estradiol.

with respect to the age-matched reference values $(\mathrm{r}=0.62, P<0.001)$, and the reduced serum IGF-1 level, also when expressed in both $\mathrm{ng} / \mathrm{ml}(\mathrm{r}=-0.49$, $P<0.05$, Fig. 1) and as percentage of age-matched reference values $(\mathrm{r}=-0.47, P=0.007)$.

The HCS was not related to serum levels of all the remaining analyzed hormones (in all cases, $P>0.2$ ).

\section{DISCUSSION}

In our study, we have demonstrated that men with mild systolic HF treated according to current guidelines manifest noticeably augmented central hypercapnic chemoreceptor sensitivity. Our observation confirms

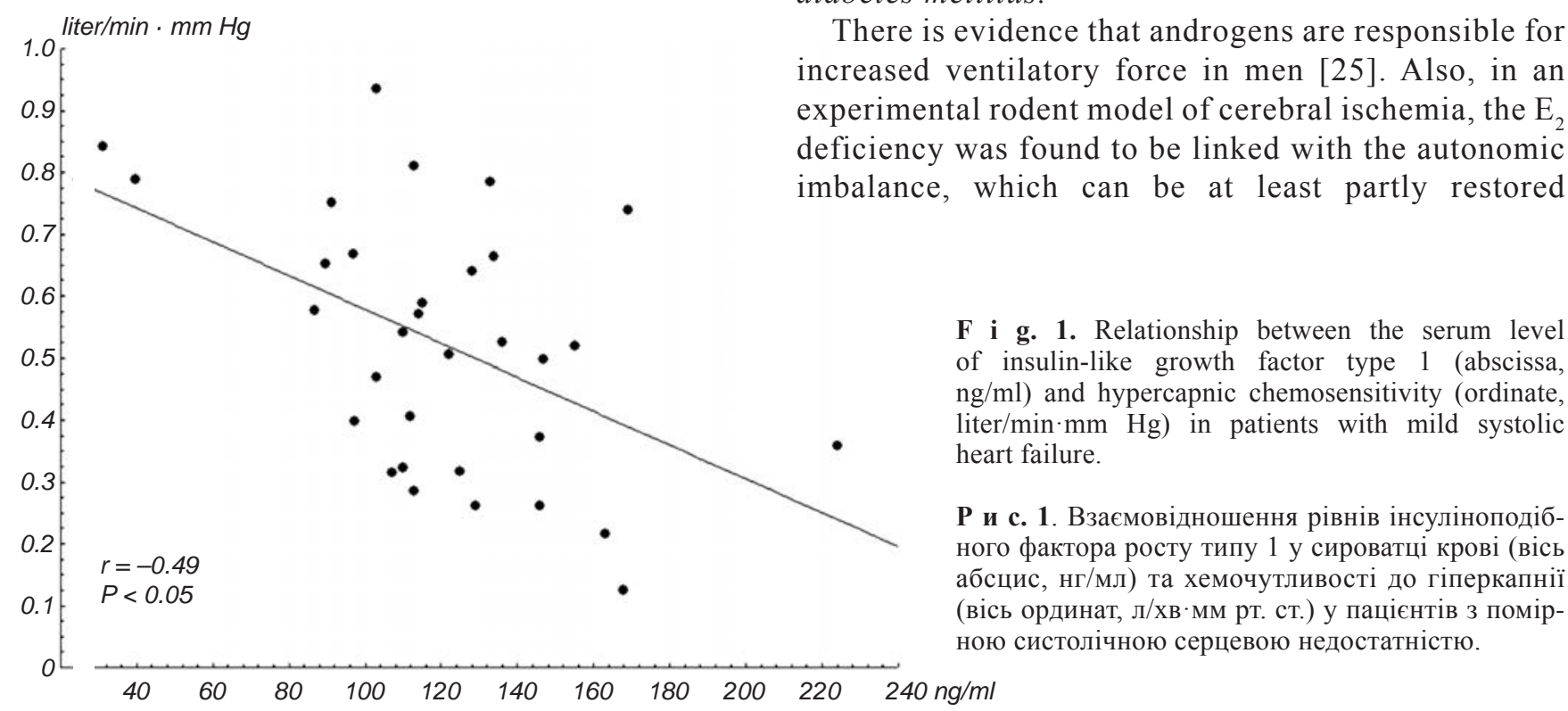

that reflex mechanisms controlling the functioning of the cardiopulmonary system are deranged at early stages of the heart disease, and therapies counteracting the overactivated renin-angiotensin-aldosterone and adrenergic systems do not bring these mechanisms to normalization [2]. It should be emphasized that we have not found any associations of the chemosensitivity with any clinical and laboratory parameters, applied treatment, and co-morbidities in men with mild systolic HF. In particular, at the early stage of heart disease, augmented hypercapnic chemoreceptor sensitivity reflects neither the HF severity, the magnitude of inflammation (expressed using serum hsCRP), the neurohormonal activation (measured using plasma NT-proBNP), and the presence of major co-morbidities, such as anemia, renal dysfunction, and diabetes mellitus.

There is evidence that androgens are responsible for increased ventilatory force in men [25]. Also, in an experimental rodent model of cerebral ischemia, the $\mathrm{E}_{2}$ deficiency was found to be linked with the autonomic imbalance, which can be at least partly restored

F i g. 1. Relationship between the serum level iter $/ \mathrm{min} \cdot \mathrm{mm} \mathrm{Hg}$ ) in patients with mild systolic

Р с. 1. Взаємовідношення рівнів інсуліноподібного фактора росту типу 1 у сироватці крові (вісь абсцис, нг/мл) та хемочутливості до гіперкапнії (вісь ординат, л/хв·мм рт. ст.) у пацієнтів 3 помір$\mathrm{g} / \mathrm{ml}$ 


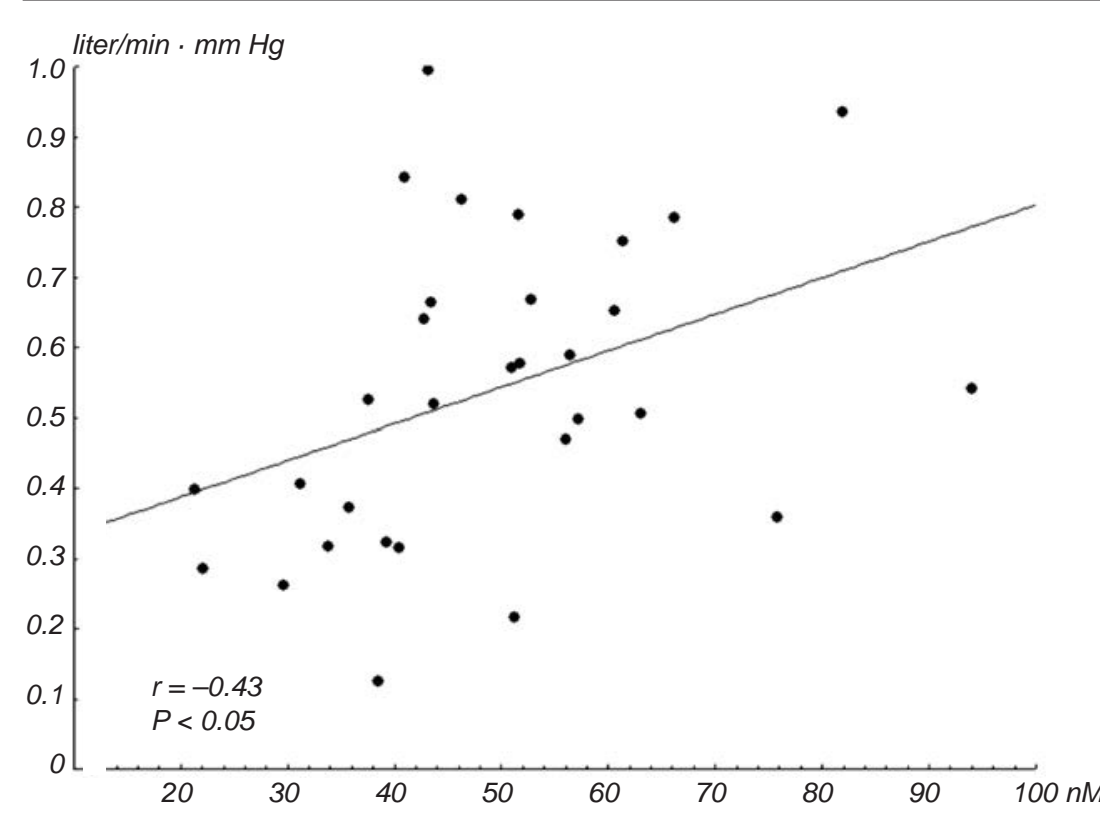

F i g. 2. Relationship between the serum level of sex hormone-binding globulin (abscissa, nM) and hypercapnic chemoreceptor sensitivity (ordinate, liter/min. $\mathrm{mm} \mathrm{Hg}$ ) in patients with mild systolic heart failure.

P и с. 2. Взаємовідношення рівнів глобуліну, що зв'язує статеві гормони (вісь абсцис, нМ), та хемочутливості до гіперкапнії (вісь ординат, л/хв·мм рт. ст.) у пацієнтів з помірною систолічною серцевою недостатністю.

during $\mathrm{E}_{2}$ supplementation [21]. However, although anticipated [25], we did not find relations between hypercapnic chemoreceptor sensitivity and circulating levels of neither TT nor $\mathrm{E}_{2}$. In this context, it is very intriguing that we have found the other relationships, i.e., between augmented HCS and low IGF-1 together with high SHBG levels in men with systolic HF. Although anticipated, we did not record any relations between the chemosensitivity and cortisol level in examined patients.

Although it is not commonly acknowledged, IGF-1 is an important modulator of the functions of the autonomic nervous system [26, 27]. Cachectic patients with HF, on the one hand, develop abnormal functioning of the growth hormone-IGF-1 axis [28], and, on the other hand, demonstrate a severe autonomic imbalance and overactivation of central chemoreceptors [28]. Moreover, we showed earlier that men with systolic HF along with IGF-1 deficiency develop exercise hyperpnea [12]. Therefore, the relationship between an overactivated chemoreflex and reduced circulating IGF-1 levels reported here might at least partly explain the previously observed phenomena.

It should be taken into account that SHBG not only is an agent responsible for the transport of steroid hormones in the circulation but also is considered a separate hormone that, through its interaction with specific receptors, can modify the metabolism of target cells, including the autonomic structures within the CNS [29]. Patients with HF demonstrate increased serum levels of SHBG accompanied by high plasma
NT-proBNP, low LVEF, and low BMI levels [30]; this constitutes an independent factor for unfavorable prognosis [30]. In other clinical settings, SHBG has been linked with the nutrition status, metabolic syndrome, hyperinsulinemia, and insulin resistance [31-33]. Our observations are the first report relating the circulating SHBG level to the efficacy of reflex control of cardiorespiratory functioning in the clinical setting of a cardiovascular disease. This relationship may be expected because the autonomic nerve centers reveal a high affinity to SHBG, and SHBG has been shown to modify the functioning of these structures in experimental studies [29].

Our study has certain limitations. The first one is the relatively low number of examined subjects with systolic HF, which is mainly due to the very laborious and time-consuming character of physiological measurements (in particular, that of HCS). Second, we would like to point out that we have assessed in our study the functioning of endocrine glands (gonads, adrenals) using baseline circulating levels of produced and released hormones without the comprehensive and dynamic assessment of the entire hypothalamichypophyseal-gonadal and hypothalamic-hypophysealadrenal axes. We believe that the latter information is not obligatory for full interpretation of the results, as the hormone parameters analyzed in our study are considered standard hormone measures used in everyday clinical practice.

Finally, we need to acknowledge the observational character of our study, as we have not assessed the 
precise mechanism responsible for the observed relationships. The above interesting and intriguing results need further experimental studies.

Thus, men with systolic HF at the early stage of heart disease demonstrate augmented HCS that is particularly increased in subjects with reduced serum IGF-1 and higher serum SHBG levels. Thus suggests that some hormones with the respective receptors in the autonomic centers may modify the reflex mechanisms of cardiorespiratory control in the clinical setting of cardiovascular pathology. Hence, modified levels of SHBG and IGF-1 may be a factor responsible for augmented ventilation and subjective feeling of dyspnea in patients with HF.

Acknowledgments. This research was financially supported by the State Committee for Scientific Research (Poland) grant No. NN519 580838 .

Ю. Майㄹ, А. Ридлевська ${ }^{1,2}$, Б. Поніковська, В. Банасяк ${ }^{l}$, П. Поніковський ${ }^{1,2}$, С. Янковська ${ }^{1,2}$

\section{ХЕМОЧУТЛИВІСТЬ ДО ГІПЕРКАПНІЇ У ПАЦІЄНТІВ ІЗ СЕРЦЕВОЮ НЕДОСТАТНІСТЮ: КОРЕЛЯЦІЯ ЗІ ЗМІЩЕННЯМИ РІВНІВ ІНСУЛІНПОДІБНОГО ФАКТОРА РОСТУ ТИПУ 1 ТА ГЛОБУЛІНУ, ЩО ЗВ'ЯЗУЄ СТАТЕВI ГОРМОНИ}

\author{
${ }^{1}$ Військовий шпиталь, Вроцлав (Польща). \\ ${ }^{2}$ Вроцлавський медичний університет (Польща). \\ Р е 3 ю м е
}

У пацієнтів із серцевою недостатністю (CH) навіть на ранніх стадіях захворювання розвивається автономний дисбаланс паралельно 3 розладами контролю серцево-судинної системи та відхиленнями метаболізму деяких гормонів від норми. Ми досліджували хемочутливість до гіперкапнії (HCS) у 34 чоловіків із СН, використовуючи метод зворотного дихання. Така чутливість визначалась як нахил лінії регресії при співставленні хвилинного об'єму вентиляції (л/хв) та кінцевої концентрації двооксиду вуглецю (мм рт. ст.). Рівні тестостерону, дигідроепіандростерону сульфату, інсулінподібного фактора росту типу $1(I G F-1)$, глобуліну, що зв'язує статеві гормони $(S H B G)$, естрадіолу та кортизолу визначали в сироватці крові, використовуючи імунологічні методики. Як виявилося, зв'язки між рівнем HCS, з одного боку, та клінічними показниками, застосованою терапією та супутніми захворюваннями - 3 другого, були відсутніми (в усіх випадках $P>0.2$ ). Підвищена HCS супроводжувалася підвищеними рівнями $S H B G$ (для концентрацій у наномолях на 1 л $\mathrm{r}=0.43, P<0.05$, а для нормованих значень, наведених щодо певної вікової групи, $\mathrm{r}=0.62, P<0.001)$ та низькими рівнями $I G F-1$ (для концентрацій у нанограмах на 1 мл та для наведених нормованих значень $\mathrm{r}=-0.49$,
$P<0.05$ та $\mathrm{r}=-0.47, P=0.007$ відповідно). Значення $\mathrm{HCS}$ не виявляли будь-яких зв'язків з рівнями всіх досліджених гормонів у сироватці. Це дозволяє думати, що гормональні стимули можуть помітно модифікувати рефлекторні механізми контролю серцево-судинної системи у клінічних випадках їі патологій.

\section{REFERENCES}

1. S. D. Anker, E. A. Jankowska, and D. O. Okonko, "Therapeutic patents for chronic heart failure: a review of patent applications from 1996 to 2002," Expert. Opin. Ther. Patents, 14, No. 5, 639-654 (2004).

2. E. A. Jankowska, P. Ponikowski, M. F. Piepoli, et al., "Autonomic imbalance and immune activation in chronic heart failure - pathophysiological links," Cardiovascul. Res., 3, 434-445 (2006).

3. V. Dubreuil, N. Ramanantsoa, D. Trochet, et al., "A human mutation in Phox $2 b$ causes lack of $\mathrm{CO}_{2}$ chemosensitivity, fatal central apnea, and specific loss of parafacial neurons," Proc. Natl. Acad. Sci. USA, 105, No. 3, 1067-1072 (2008).

4. J. A. Soares Barreto-Filho, F. M. Consolim-Colombo, H. Ferreira Lopes, et al., "Dysregulation of peripheral and central chemoreflex responses in Chagas' heart disease patients without heart failure," Circulation, 104, No. 15, 1792-1798 (2001).

5. P. Ponikowski, T. P. Chua, S. D. Anker, et al., "Peripheral chemoreceptor hypersensitivity: an omnous sign in patients with chronic heart failure," Circulation, 104, 544-549 (2001).

6. P. Ponikowski, T. P. Chua, M. Piepoli, et al., "Augmented peripheral chemosensitivity as a potential input to baroreflex impairment and autonomic imbalance in chronic heart failure," Circulation, 96, No. 8, 2586-2594 (1997).

7. T. Kara, K. Narkiewicz, and V. K. Somers, "Chemoreflexes physiology and clinical implications," Acta Physiol. Scand., 177, No. 3, 377-384 (2003).

8. J. M. Nappi and A. Sieg, "Aldosterone and aldosterone receptor antagonists in patients with chronic heart failure," Vascul. Health Risk Manag., 7, 353-363 (2011).

9. E. A. Jankowska, B. Biel, J. Majda, et al., “Anabolic deficiency in men with chronic heart failure: Prevalence and detrimental impact on survival," Circulation, 114, 1829-1837 (2006).

10. E. A. Jankowska, J. Jakubaszko, A. Cwynar, et al., "Bone mineral status and bone loss over time in men with chronic heart failure," Eur. J. Heart Fail., 11, No. 1, 28-38 (2009).

11. E. A. Jankowska, A. Drohomirecka, B. Ponikowska, et al., "Deficiencies in circulating testosterone and dehydroepiandrosterone sulfate and depression in men with systolic chronic heart failure," Eur. J. Heart Fail., 12, No. 9, 966-972 (2010).

12. E. A. Jankowska, G. Filippatos, B. Ponikowska, et al., "Reduction in circulating testosterone relates to exercise capacity in men with chronic heart failure," J. Card. Fail., 15, No. 5, 442-450 (2009).

13. E. A. Jankowska, K. Wegrzynowska-Teodorczyk, B. Ponikowska, et al., "Combined testosterone and insulin-like growth factor deficiency impairs quadriceps strength in men with chronic heart failure," Eur. Heart J., 29, Abstract Suppl., 306 (2008).

14. E. A. Jankowska, J. Maj, B. Ponikowska, et al., "Deficiencies 
in testosterone and insulin-like growth factor type 1 predict the occurrence of anemia in men with systolic chronic heart failure," Eur. Heart J., 30, Abstract Suppl., 830 (2009).

15. E. A. Jankowska, A. Drohomirecka, B. Ponikowska, et al., "Deficiencies in circulating testosterone and dehydroepiandrosterone sulfate, and depression in men with systolic chronic heart failure," Eur. J. Heart Fail., 12, No. 9, 966-973 (2010).

16. E. A. Jankowska, P. Rozentryt, B. Ponikowska, et al., "Circulating estradiol and mortality in men with systolic chronic heart failure," J. Am. Med. Assoc., 301, No. 18, 18921901 (2009).

17. B. Stoffel-Wagner, "Neurosteroid metabolism in the human brain," Eur. J. Endocrinol., 145, No. 6, 669-679 (2001).

18. E. P. Gomez-Sanchez, "Mineralocorticoid receptors in the brain and cardiovascular regulation: minority rule?" Trends Endocrinol. Metab., 22, No. 5, 179-187 (2011).

19. U. Schibler and S. A. Brown, "Enlightening the adrenal gland," Cell Metab., 2, No. 5, 278-281 (2005).

20. V. Joseph, Y. Dalmaz, J. M. Cottet-Emard, and J. M. Pequignot, "Dexamethasone's influence on tyrosine hydroxylase activity in the chemoreflex pathway and on the hypoxic ventilatory response," Pflügers Arch., 435, No. 6, 834-839 (1998).

21. T. M. Saleh, A. E. Cribb, and B. J. Connell, "Estrogen-induced recovery of autonomic function after middle cerebral artery occlusion in male rats," Am. J. Physiol. (Regulat. Integrat. Comp. Physiol.), 281, No. 5, 1531-1539 (2001).

22. L. J. DeGroot and J. L. Jamesom, Endocrinology, Elsevier Saunders, Philadelphia (2006).

23. T. P. Chua, P. Ponikowski, and A. J. Coats, "Chemoreflexes in heart failure," Circulation, 96, No. 6, 2090-2091 (1997).

24. A. Rydlewska, B. Ponikowska, L. Borodulin-Nadzieja, et al., "Assessment of chemoreflex involved in reflex cardiorespiratory control," Przegl. Lek., 68, No. 3, 179-183 (2011).

25. D. P. White, B. K. Schneider, R. J. Santen, et al., "Influence of testosterone on ventilation and chemosensitivity in male subjects," J. Appl. Physiol., 59, No. 5, 1452-1457 (1985).

26. R. R. Grunstein, K. Y. Ho, M. Berthon-Jones, et al., "Central sleep apnea is associated with increased ventilatory response to carbon dioxide and hypersecretion of growth hormone in patients with acromegaly," Am. J. Respir. Crit. Care Med., 150, No. 2, 496-502 (1994).

27. R. E. Schmidt, D. A. Dorsey, L. N. Beaudet, et al., "Insulinlike growth factor I reverses experimental diabetic autonomic neuropathy," Am. J. Pathol., 155, No. 5, 1651-1660 (1999).

28. S. D. Anker, M. Volterrani, C. D. Pflaum, et al., "Acquired growth hormone resistance in patients with chronic heart failure: implications for therapy with growth hormone," J. Am. Coll. Cardiol., 38, No. 2, 443-452 (2001).

29. E. A. Jankowska and P. Ponikowski, "Sex hormone-binding globulin and heart failure: a passive carrier of steroid hormones or an active hormone itself?" Rev. Esp. Cardiol., 62, No. 12, 1353-1355 (2009).

30. D. A. Pascual-Figal, P. L. Tornel, F. Nicolás, et al., "Sex hormone-binding globulin: a new marker of disease severity and prognosis in men with chronic heart failure," Rev. Esp. Cardiol., 62, No. 12, 1381-1387 (2009).

31. J. D. Caldwell, R. A. Shapiro, G. F. Jirikowski, and F. Suleman, "Internalization of sex hormone-binding globulin into neurons and brain cells in vitro and in vivo," Neuroendocrinology, 86, No. 2, 84-93 (2007).

32. A. S. Morisset, K. Blouin, and A. Tchernof, "Impact of diet and adiposity on circulating levels of sex hormone-binding globulin and androgens," Nutr. Rev., 66, 506-516 (2008).

33. A. Onat, G. Hergenç, A. Karabulut, et al., "Serum sex hormonebinding globulin, a determinant of cardiometabolic disorders independent of abdominal obesity and insulin resistance in elderly men and women," Metabolism, 56, 1356-1362 (2007). 